\section{Goodpasture's Syndrome: Survival after Acute Renal Failure}

Brit. med. F., 1967, 4, 95

Goodpasture's syndrome, the combination of haemoptysis and nephritis, is being recognized with increasing frequency (Davidson et al., 1966). In its classical form it comprises a distinct clinical entity to which the term "lung purpura with nephritis" has been applied (Rusby and Wilson, 1965). This paper provides the first report of a patient with this condition who recovered after an episode of acute renal failure.

\section{CASE REPORT}

A 27-year-old mechanical engineer was admitted to hospital on 9 October 1965. He gave a history of persistent haemoptysis for seven months, increasing breathlessness for three months, macroscopic haematuria for one week, and failure to pass urine for 36 hours. He was afebrile, pale, and orthopnoeic. The blood pressure was $110 / 70 \mathrm{~mm}$. $\mathrm{Hg}$ and there were crepitations over the right lower chest.

Investigations.-Blood urea $170 \mathrm{mg} . / 100 \mathrm{ml}$; s serum $\mathrm{Na}+129$ $\mathrm{mEq} / \mathrm{l}$; $\mathrm{K}+3.4 \mathrm{mEq} / \mathrm{l}$; $\mathrm{HCO}_{3}{ }^{-} 17 \mathrm{mEq} / \mathrm{l}$; calcium $9.2 \mathrm{mg} . /$ $100 \mathrm{ml}$.; phosphate $6.0 \mathrm{mg} . / 100 \mathrm{ml}$. Liver-function tests normal. Serum proteins: total $6.1 \mathrm{~g} . / 100 \mathrm{ml}$. (albumin $2.6 \mathrm{~g}$., globulin alpha 10.4 g., alpha 1.2 g., beta 0.5 g., gamma 1.4 g.). Hb 8.7 g./ 100 ml. ; P.C.V. $30 \%$; M.C.H.C. $29 \%$; E.S.R. 94 mm./1st hour (Westergren); W.B.C. $13,700 / \mathrm{cu} . \mathrm{mm}$. (normal differential count); reticulocytes less than $1 \%$; prothrombin time 17 seconds (control 11 seconds). Blood coagulation mechanism otherwise normal. Serum iron $25 \mu \mathrm{g} . / 100 \mathrm{ml}$., total iron binding capacity $435 \mu \mathrm{g} . /$ $100 \mathrm{ml}$. Coombs test, antinuclear factor, L.E. cells all negative. Antistreptolysin titre less than 100 Todd units; blood cultures negative; sputum and throat culture, a few beta-haemolytic streptococci (Lancefield group A). The E.C.G. was normal, but chest $x$-ray examination showed patchy consolidation at both lung bases. Numerous haemosiderophores were present in the sputum. Bronchoscopy and bronchography were normal, as were cystoscopy and retrograde pyelography.

Histological examination of renal tissue obtained on 12 October and reported by Dr. M. K. McDonald showed a moderately severe acute proliferative glomerulonephritis, with epithelial crescent formation, a few small foci of glomerular necrosis, but no generalized obliteration of glomerular structure. There was some evidence of acute tubular necrosis. Arteritis was not demonstrable.

$\mathrm{He}$ was treated with penicillin but continued to have haemoptyses and remained anuric. Four days after admission the blood urea had risen to $266 \mathrm{mg} . / 100 \mathrm{ml}$., and peritoneal dialysis was begun with rapid improvement. On 27 October he passed urine for the first time for 20 days. On 29 October dialysis was discontinued. The blood urea which had fallen to $76 \mathrm{mg}$. rose to $138 \mathrm{mg}$., but then fell spontaneously as renal function steadily improved. During this period he had another episode of haemoptysis associated with sore throat, radiological evidence of further intrapulmonary haemorrhage, and the antistreptolysin $\mathrm{O}$ titre rose to greater than 2,000 Todd units. A further course of penicillin was given, and by discharge on 20 December he was clinically well and has remained well. The blood pressure was $140 / 90 \mathrm{~mm} . \mathrm{Hg}, \mathrm{Hb}$ 17.4 g./100 ml., E.S.R. 7 mm./1st hour, blood urea 29 mg. $/ 100 \mathrm{ml}$, and creatinine clearance $100 \mathrm{ml} . / \mathrm{min}$. There was no haematuria but moderately heavy proteinuria persisted. A second renal biopsy, performed on 29 November 1966, showed complete hyalinization of a small number of glomeruli: the remainder showed only a minor degree of endothelial swelling and focal endothelial cell proliferation and no crescents were visible.

\section{COMMENT}

Goodpasture's syndrome can be distinguished histologically from polyarteritis nodosa by the absence of significant arteritis, and is thought by some to be related to idiopathic pulmonary haemosiderosis (Elder et al., 1965). The cause is obscure, though there is evidence to suggest a hypersensitivity or immunological reaction (Duncan et al., 1965). Streptococcal infection is not thought to be important, though cases with high antistreptolysin $\mathrm{O}$ titres have been described (Lundberg, 1963 ; Sprecace, 1963 ; McCall et al., 1965).

In 1964 Benoit et al. reviewed 52 cases, by 1966 Davidson et al. increased the number to 105 , and there are at least 38 further cases in the literature, bringing the total to 143 . Goodpasture's syndrome is often fatal, death resulting either from massive pulmonary haemorrhage or from renal failure. Eighteen of the many patients reported as dying of uraemia have been dialysed, sometimes inadequately by present standards. Two patients who had been dialysed were still alive at the time of reporting: one has been maintained by intermittent haemodialysis (Freeman et al., 1966), and the other was alive 16 months after renal transplantation (Cleveland et al., 1964). Twenty-one other reported cases of Goodpasture's syndrome have survived (Bloom et al., 1965 ; Duncan et al., 1965; Elder et al., 1965 ; McCall et al., 1965 ; Pasternack et al., 1965; Portwich and Encke, 1965 ; Sybers et al., 1965). In the majority the renal involvement, where detailed, comprised proteinuria and haematuria without deterioration of renal function. Thirteen were treated with steroids, seven improved spontaneously, and details of therapy are not mentioned in the others.

In the present case the course of the illness was initially characteristic of Goodpasture's syndrome, but the severity of the renal failure seemed disproportionate to the pathological appearances in the glomeruli and may have been partly accounted for by the coexistent tubular changes. None the less, recovery after prolonged anuria or oliguria due to any form of glomerulonephritis is said to be very uncommon (Persoff, 1965). This is the first reported case of Goodpasture's syndrome where such recovery has occurred. With adequate dialysis other patients may survive and all uraemic patients with Goodpasture's syndrome should be treated as if suffering from potentially reversible acute renal failure.

Our patient received neither steroids nor immunosuppressive therapy, and there is no evidence to suggest that these drugs are of value during the acute uraemic phase.

\section{J. F. MUNRO, M.B., M.R.C.P.ED. A. M. GEDDES, M.B., M.R.C.P.ED. W. L. LAMB, M.B., F.R.C.P.ED.}

Royal Infirmary, Edinburgh 3.

\section{REFERENCES}

Benoit, F. L Rulon D. B. Theil, G. B., Doolan, P. D., and Watten, R. H. (1964). Amer. F. Med., 37, 424.

Bloom, V. R., Wayne, D. J., and Wrong, O. M. (1965). Ann. intern. Med., 63, 752 .

Cleveland, R. J., Lee, H. M. Prout, G. R., and Hume, D. M. (1964). Surg. Gynec. Obstet., 119, 991.

Davidson, M. B., Cutler, R. E., and Schuldberg, I. I. (1966). Arch. intern. Med., 117, 652.

Duncan D. A. Drummond, K. N., Michael, A. F., and Vernier, R. L. (1965). Ann. intern. Med., 62, 920.

Elder, J. L., Kirk, G. M., and Smith, W. G. (1965). Brit. med. F., 2, 1152.

Freeman, R. M., Vertel, R. M., and Easterling, R. E. (1966). Arch. intern. Med., 117, 643.

Lundberg, G. D. (1963). F. Amer. med. Ass., 184, 915.

McCall, C. B., Harris, T. R., and Hatch, F. E. (1965). Amer. Rev. resp. Dis., 91, 424.

Pasternack, A., Linder, E., and Kuhlbäck, B. (1965). Acta med. scand., 177,601 .

Persoff, D. (1965). Lancet, 1, 347.

Portwich, F., and Encke, A. (1965). Dsch. Arch. klin. Med., 210, 48. Rusby, N. L., and Wilson, C. (1965). Ann. Rev. Med., 16, 301.

Sprecace, G. A. (1963). Amer. Rev. resp. Dis., 88, 330.

Sybers, R. G., Sybers, J. L., Dickie, H. A., and Paul, L. W. (1965). Amer. F. Roentgenol., 94, 674. 